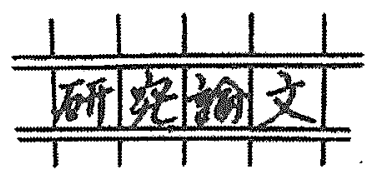

\title{
高圧下におけるメタン一酸素同軸乱流非予混合火炎の数值解析
}

\section{Numerical Simulation of High Pressure Methane-Oxygen Coaxial Turbulent Nonpremixed Flames}

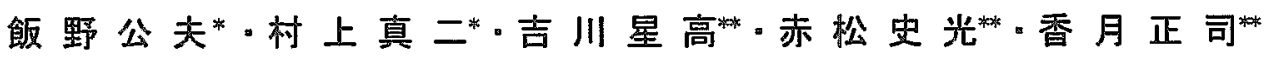 \\ Kimio IINO, Shinji MURAKAMI, Hoshitaka KIKKAWA, Fumiteru AKAMATSU and Masashi KATSUKI
}

(Received November 19, 2004)

\begin{abstract}
We carried out the numerical simulation of methane-oxygen coaxial turbulent nonpremixed flames and of non-combusting flows at high pressures. The main objectives of this research were to assess the potential of several turbulence models and combustion models for their abilities to predict the characteristics of high pressure combustion. Four combinations of numerical models were studied: (1) a PDF model with $k-\varepsilon$ model, (2) a flamelet model with $k-\varepsilon$ model, (3) a PDF model with Reynolds stress model (RSM), and (4) a flamelet model with RSM. Comparison of the numerical results with measurement data under high pressure conditions revealed: (a) good agreement of the $k-\varepsilon$ model for corresponding cold jets with increasing pressure; (b) a greater effect of the $k-\varepsilon$ model and RSM on flow field characteristics than combustion models at high pressure; (c) good predictions, with the exception of turbulent energy, with the RSM/PDF model.
\end{abstract}

Key Words: Oxygen Combustion, Turbulent Non-Premixed Flame, High Pressure Combustion, Numerical Simulation

\section{1. 緒 言}

酸素燃焼はエネルギー効率の向上と環境負荷低減をもたら す技術として,多くの工業プロセスに導入が進んでいる ${ }^{3-5)}$ 。 また，近年次世代燃料として注目を集めているDME の製造 プロセスで必要な合成ガスに関して、筆者らは天然ガスと酸 素を原料とする部分酸化法を利用した高圧下での合成ガス発 生装置の開発を進めている。しかしながら，酸素燃焼に関す る情報は限られたものしか存在せず6,7), 特に高急荷化の観点 から重要である高圧下での燃焼挙動に関する情報は極めて少 ないものとなっており, 詳細な然焼挙動に関する実験データ は存在しない。さらにバーナおよび炉体設計に必要不可欠で ある RANS（Reynolds-Averaged Navier-Stokes）を活用しての 数值流体解析(CFD)に関しては，各種モデルの高圧下での適 用性に関して評価された研究例は存在せず, 広く利用されて いる乱流モデルや乱流燃焼モデルがどの程度高圧燃焼場で適 用可能なものであるのかを検証する必要性がある。そこで筆 者らは, 高圧下での連続燃焼試験を可能とする実験設備を製 作し，メタン一酸素同軸乱流非予混合火炎を対象に，非燃焼 時と燃焼時の流動場に詨して LDV 計測を行い，乱流構造に 関して両者の比較・検討を行うとともに, 圧力による火炎構 造の变化に注目して高圧燃焼場でのデータ収集を行ってき
$た^{1,2)}$ 。

本稿では,メタン一酸素同軸乱流非予混合火炎の数值解析 を実施して，高圧下で収集した詳細な計測データと比較・検 証することによって，高圧下での乱流モデルおよび乱流燃焼 モデルの適用性評価を行うことを目的とし，その検討結果に ついて報告する。

\section{2. 解析方法および解析対象}

\section{1 乱流モデル}

今回の数值解析では沉用数值解析コード FLUENT を使用 した。質量，運動量，エネルギー保存式を以下に示す。

$$
\begin{aligned}
& \frac{\partial}{\partial x_{i}}\left(\rho u_{i}\right)=0 \\
& \frac{\partial}{\partial x_{i}}\left(\rho u_{i} u_{j}\right)=-\frac{\partial p}{\partial x_{i}}+\frac{\partial}{\partial x_{i}}\left(2\left(\mu+\mu_{i}\right) D_{i j}\right)
\end{aligned}
$$

ただし， $D_{i j}$ はひずみ速度テンソルである。

$$
D_{i j}=\frac{1}{2}\left(\frac{\partial u_{i}}{\partial x_{j}}+\frac{\partial u_{j}}{\partial x_{i}}\right)
$$

*大陽日酸株式会社＼cjkstart燃焼技術センター(テ 408-0015 山梨県北杜市高根町下黒沢 3054-3)

Combustion Technology Center, Taiyo Nippon Sanso Corporation, (3054-3 Shimokurosawa, Takanecho, Hokuto, Yamanashi 408-0015, Japan) **大阪大学大学院工学研究科機械物理工学専攻(广565-0871 大阪府吹田市山田丘 2-1)

Department of Mechanophysics Engineering, Osaka University (2-1 Yamadaoka, Suita, Osaka 565-0871, Japan) 


$$
\frac{\partial}{\partial x_{i}}\left(u_{i} \rho H\right)=\frac{\partial}{\partial x_{i}}\left(\frac{\mu_{t}}{P r_{t}} \frac{\partial H}{\partial x_{i}}\right)+S_{H}
$$

ここで, 粘性散逸は無視し，生成項には放射によるエネル ギー生成を慮している。放射伝熱モデルには $\mathrm{DOM}^{8,9}$

(Discrete Ordinate Method) を用いて放射伝熱方程式 (RTE : Radiation Transfer Equation）を解き，放射によるエネルギー 生成を算出する。ここで, $u_{i}: x_{i}$ 方向の平均速度, $: \rho$ 流 体密度, $p$ : 压力, $\mu$ : 粘度, $\mu_{t}$ : 乱流粘度, $H$ : 全エン タルピ, $P r_{t}$ : 乱流プラントル数, $S_{H}$ : 全エンタルピ形式 エネルギー保存則生成項である。

今回の数值解析では, 乱流モデルとして広く利用されてい る標準 $k-\varepsilon 2$ 方程式モデル ${ }^{00}$ と高圧場では乱流の非等方性が 増大するという報告 ${ }^{2}$ から，その点を考慮可能なモデルとし てレイノルズ応力モデル $(\mathrm{RSM})^{11)}$ を使用した。以下に $k$ と $\varepsilon$ に対する輸送方程式を示す。

乱流エネルギー $k$ の輸送方程式は，

$$
\frac{\partial}{\partial x_{i}}\left(u_{i} \rho k\right)=\frac{\partial}{\partial x_{i}}\left(\mu+\frac{\mu_{t}}{\sigma_{k}}\right) \frac{\partial k}{\partial x_{i}}+G_{k}-\rho \varepsilon
$$

$G_{k}$ は平均速度勾配による乱流エネルギーの生成であり， 以下の式で定義する。

$$
G_{k}=\mu_{t} \frac{1}{2}\left(\frac{\partial u_{i}}{\partial x_{j}}+\frac{\partial u_{j}}{\partial x_{i}}\right)^{2}
$$

$\mu_{t}$ は乱流粘度で，以下の式で表される。

$$
\mu_{t}=\rho C_{\mu} \frac{k^{2}}{\varepsilon}
$$

乱流エネルギー消散率 $\varepsilon$ の輸送方程式は,

$$
\frac{\partial}{\partial x_{i}}\left(u_{i} \rho \varepsilon\right)=\frac{\partial}{\partial x_{i}}\left(\mu+\frac{\mu_{t}}{\sigma_{\varepsilon}}\right) \frac{\partial \varepsilon}{\partial x_{i}}+C_{1 \varepsilon} \frac{\varepsilon}{k} G_{k}-C_{2 \varepsilon} \rho \frac{\varepsilon^{2}}{k}(8)
$$

$C_{1 \varepsilon}, C_{2 \varepsilon}$ は経験定数であり， $\sigma_{k}$ は $k$ に対する乱流プラン トル数, $\sigma_{\varepsilon}$ は $\varepsilon$ に対する乱流プラントル数である。標準 $k-\varepsilon 2$ 方程式モデルで用いられるモデル定数は，以下の值とした。 $C_{J_{\varepsilon}}=1.44, C_{2 \varepsilon}=1.92, C_{\mu}=0.09, \sigma_{k}=1.0, \sigma_{\varepsilon}=1.3, P_{t}$ $=0.9$

次に, RSM では個々のレイノルズ応力, $\overline{u_{i}^{\prime} u_{j}^{\prime}}$ を輸送方 程式を用いて計算し，運動量方程式を閒じるために用いる。 レイノルズ応力輸送方程式では以下のモデル化を行い, 連立 方程式を解いた。

乱流拡散項のモデル化では以下のようにスカラーの乱流拡 散係数老用いる。

$$
D_{T, i j}=\frac{\partial}{\partial x_{k}}\left(\frac{\mu_{t}}{\sigma_{k}} \frac{\partial \overline{u_{i}^{\prime} u_{j}^{\prime}}}{\partial x_{k}}\right)
$$

乱流粘度は式(7)を用いて計算される。ここで， $\sigma_{k}=0.82$ を用いた。

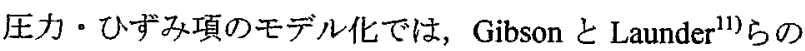

提案に従い，モデル化を行った。

散逸項のモデル化については標集 $k-\varepsilon 2$ 方程式モデルで用 いたものと同じモデル輸送方程式を用いて計算する。経験定 数については, 標準 $k-\varepsilon 2$ 方程式モデルと同様の值を用いる。

\section{2 乱流燃焼モデル}

今回解析対象とするメタンー酸素燃焼火炎においては, 化 学反忘は十分に速く, 燃焼は流体の混合問題に簡略化される と考えられるため，燃焼モデルとして混合分率法 ${ }^{12)}$ (以降， PDF モデル）を採用した。PDF モデルでは混合分率 $f$ につ いて保存式を解き, 確立密度関数 (PDF) により, 乱流と化 学反応の相互作用を考虑している。また, 非平衡性を考慮す るモデルとして Flamelet モデル13)でも計算を行った。

以下に混合分率 $f$ の輸送方程式を示す。

$$
\frac{\partial}{\partial x_{i}}\left(u_{i} \rho f\right)=\frac{\partial}{\partial x_{i}}\left(\frac{\mu_{i}}{\sigma_{i}} \frac{\partial f}{\partial x_{i}}\right)
$$

ここで，混合分率 $f$ は以下で定義される。

$$
f=\frac{Z_{i}-Z_{i, o x}}{Z_{i, f u}-Z_{i, o x}}
$$

$Z_{i}$ は元素 $i$ の質量分率, 下付添字 $O x$ は酸化剂流れ入口で の值，fuは燃料流れ入口での值を示す。

混合分率は乱流中で変動している量であり, 混合分率分散 (平均值のまわりの 2 次モーメント) $g$ を定義し, その保 存式を解く必要がある。

$$
\begin{aligned}
& g=\overline{(f-\tilde{f})^{2}} \\
& \frac{\partial}{\partial x_{i}}\left(u_{i} \rho g\right)=\frac{\partial}{\partial x_{i}}\left(\frac{\mu_{t}}{\sigma_{i}} \frac{\partial g}{\partial x_{i}}\right)+C_{g} \mu_{i} \frac{\partial \tilde{f}}{\partial x_{i}}-C_{d} \rho g \frac{\varepsilon}{k}
\end{aligned}
$$

定数は以下の通りとした。

$\sigma_{t}=0.85, C_{g}=2.86, C_{d}=2$

今回の解析では, PDF 形状として $\beta$ 関数を仮定して計算 を害行した。またあらかじめ 20 種の化学種を考慮して， ルッタアップテーブルを作成した。

Flamelet モデルでは, 乱流火炎を Flamelet (火炎片) と呼 ばれる離散化した定常層流火炎の集合体とモデル化する。㹡 散火炎においては，然料および酸化郕は分子レベルで反応領 域に拡散していくが, そこで温度やラジカル化学種の影響を 受けて着火する。反応領域ではさらに多くの熱やラジカル化 学種が生成され，一部分は拡散により反応帯から失われる。 平衡に近い火炎では反応速度は拡散速度よりはるかに速くな るが，乱流による流体力学的ひずみを受け，火炎がひずすと 化学種の濃度勾配および温度勾配は急峻になり,ラジカル化 学種と熱は急速に火炎の外一と拡散していく。それによって 局所非平衡が生じやすくなる。

今回の計算では乱流における Flameletを表す一般的な層流 火炎として，対向流拡散火炎を使用した。筆者らは既報 ${ }^{1)}$ 
て,メタン一酸素対向流拡散火炎の火炎特性が高压下におい ても流体力学的ひずみによって強く影響を受けることを報告 しており,特にノズル近傍の強いひずみを受ける領域での数 值解析における比較では, 本モデル採用の適用性検討は大変 重要である。

対向流拡散火炎片のひずみ率 $a_{s}$ は，以下に定義できる。 $a_{s}=v / 2 d$

ただし， $v$ : 燃料噴流およひ酸化剂噴流速度， $d$ : 噴流

\section{ズル間距離}

ひずみ率を使用して平衡からの逸脱度を定量化する代わり

に， $\chi$ で表されるスカラー散逸を使用する。スカラー散逸

は，次式で定義する。

$$
\chi=2 D|\nabla f|^{2}
$$

ここで, $D:$ 桩散係数である。

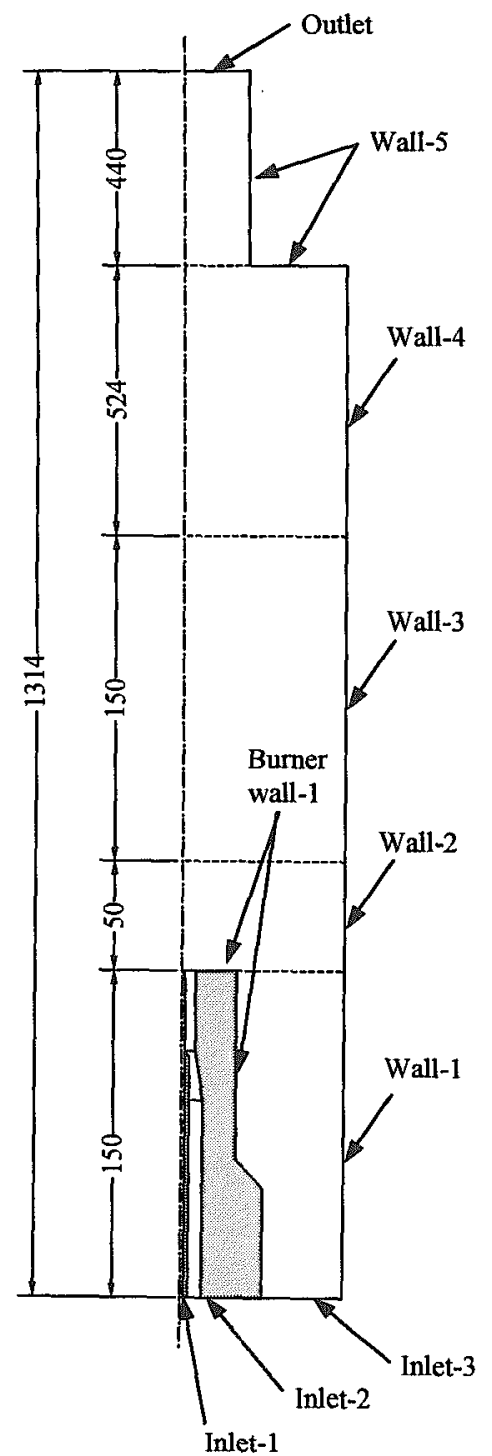

スカラー散逸 $\chi$ は火炎片の軸に沿って変化する。対向流 の形状では， $a_{s}$ は $f$ が化学量論値である点におけるスカラ 一散逸と関連付けられ，次式で表される。

$$
\chi_{s t}=\frac{a_{s} \exp \left(2\left[\operatorname{erfc^{-1}}\left(2 f_{s t}\right)\right]^{2}\right)}{\pi}
$$

ここで, $\chi_{s t}$ : 化学量論混合分率でのスカラー散逸, $f_{s t}$ : 化学量論混合分率, 式 $\operatorname{erf} c^{-1}$ : 余誤差関数である。

化学種の質量分率, 温度, 密度などのスカラーは $f$ と $\chi_{s t}$ の PDF から次式で表される。

$$
\bar{\phi}=\iint \phi\left(f, \chi_{s t}\right) p\left(f, \chi_{s t}\right) d f d \chi_{s t}
$$

今回の計算では， $f$ および $\chi_{s t}$ は統計的に独立していると 仮定し, ジョイント PDF $p\left(f, \chi_{s t}\right)$ は, $p_{f}(f) p_{\chi}\left(\chi_{s t}\right)$ の形に 簡略化し， $p_{f}$ には $\beta$ PDF の形状を，また $p_{\chi}$ にはダブルデ

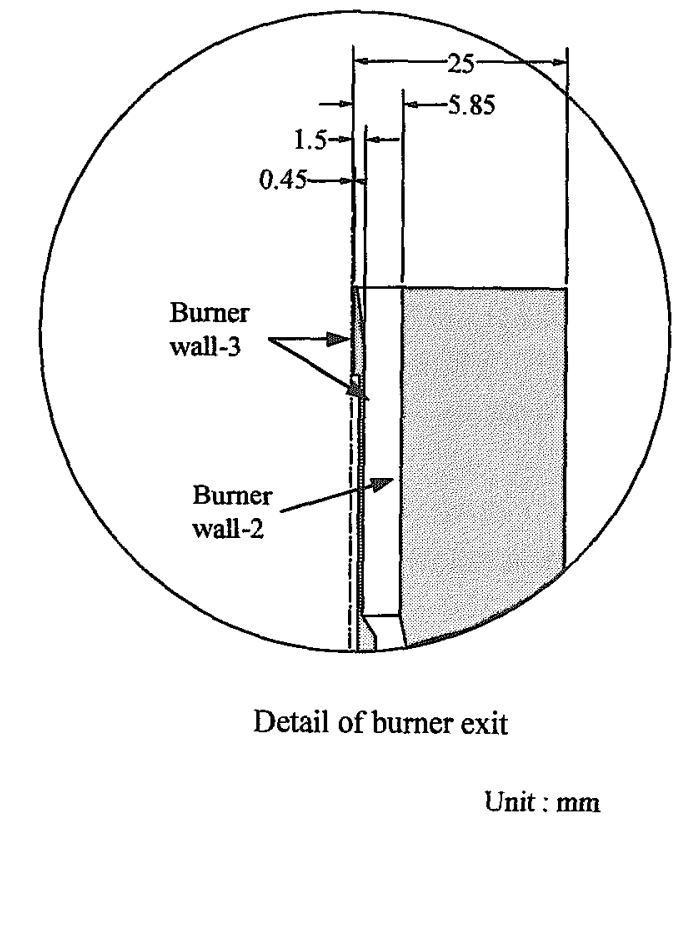

Fig. 1 Computational domain 
高 温 学 会誌第31巻第2 号 (2005 年 3 月)

Table 1 Calculation parameters on cold flow

\begin{tabular}{llccccc}
\hline \multicolumn{1}{c}{ Pressure } & & $\mathrm{MPa}$ & 0.2 & 0.5 & 0.7 & 1.0 \\
\hline $\mathrm{N}_{2}$ mass flow rate (Fuel nozzle) & Inlet-1 & $\mathrm{kg} / \mathrm{h}$ & 0.370 & 0.925 & 1.295 & 1.850 \\
$\mathrm{~N}_{2}$ mass flow rate (Oxidizer nozzle) & Inlet-2 & $\mathrm{kg} / \mathrm{h}$ & 0.888 & 2.220 & 3.108 & 4.440 \\
$\mathrm{~N}_{2}$ mass flow rate (Outer flow) & Inlet-3 & $\mathrm{kg} / \mathrm{h}$ & 0 & 0 & 0 & 0 \\
\hline
\end{tabular}

Table 2 Calculation parameters on combusting flow

\begin{tabular}{lccccc}
\hline \multicolumn{1}{c}{ Pressure } & & $\mathrm{MPa}$ & 0.5 & 0.7 & 1.0 \\
\hline $\mathrm{CH}_{4}$ mass flow rate (Fuel nozzle) & Inlet- 1 & $\mathrm{~kg} / \mathrm{h}$ & 0.531 & 0.743 & 1.062 \\
$\mathrm{O}_{2}$ mass flow rate (Oxidizer nozzle) & Inlet-2 & $\mathrm{kg} / \mathrm{h}$ & 2.540 & 3.556 & 5.080 \\
$\mathrm{O}_{2}$ mass flow rate (Outer flow) & Inlet- 3 & $\mathrm{~kg} / \mathrm{h}$ & 5.080 & 5.080 & 5.080 \\
Thermal input & - & $\mathrm{kW}$ & 7.5 & 10.5 & 15.0 \\
\hline
\end{tabular}

Table 3 Wall temperature conditions on combusting flow

\begin{tabular}{lcccc}
\hline Pressure & MPa & 0.5 & 0.7 & 1.0 \\
\hline Wall-1 & $\mathrm{K}$ & 316 & 326 & 333 \\
Wall-2 & $\mathrm{K}$ & 397 & 550 & 613 \\
Wall-3 & $\mathrm{K}$ & 476 & 744 & 875 \\
Wall-4 & $\mathrm{K}$ & 555 & 939 & 1138 \\
\hline Wall-5 & $\mathrm{K}$ & 555 & 763 & 909 \\
\hline
\end{tabular}

ルタPDF の形状を仮定して計算を実行した。また, 平均ス カラー散逸率は以下のようにモデル化する。

$$
\overline{\chi_{s t}}=\frac{C_{\chi} \varepsilon \overline{f^{\prime 2}}}{k}
$$

ここで， $C_{\chi}$ : 経験定数で今回は 2.0 使用した ${ }^{14)}$ 。 また，あらかじめルックアップテーブルを作成する際の 1 次元対向流拡散火炎を用いた計算では詳細化学反応機構に NOx 関連反応を削除した GRI-Mech3.0を採用し，34 個の化 学種, 219 個の素反応数を考虑した。

\section{3 計算領域}

実験条件に合わせた計算領域を模式的に Fig.1 に示す。非 燃焼時および然焼時の流量条件をそれぞれ Table 1，2 に示 す。解析対象は燃料ノズル中心軸に対して軸対称であるので 2 次元軸対称として,さらに炉内壁温度およびバーナ表面温 度に関しては, Table 3 に示す各測定条件での測定中の平均 温度を境界条件として計算を実行した。計算格子数は解析領 域全部で 21,833 とした。

\section{3. 解析結果}

\section{1 非燃焼時の乱流モデルの比較}

はじめに，非燃焼時について標準 $k-\varepsilon 2$ 方程式モデルと RSM 2 つの乱流モデルの比較を行う。压力は $0.2,0.5$, $0.7,1.0 \mathrm{MPa} の 4$ 条件について比較した。Fig.2 に圧力 0.2, $0.5,0.7,1.0 \mathrm{MPa}$ における軸方向平均流速の中心軸上分布

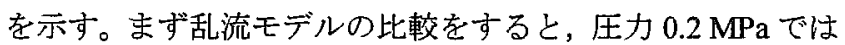
噴出直後の $\mathrm{z} / \mathrm{d}=5$ 程度まで $k-\varepsilon$ モデルの方が流速を大きく見 積むっており，それ以降では常に RSMの方が大きな值を示 している。圧力 $0.5 \mathrm{MPa}$ 以上では全ての位置で RSM での計 算值が大きな值となっている。全ての圧力条件で $\mathrm{z} / \mathrm{d}=20$ 程 度までは速度減衰の公配が急峻であるため, モデル間の計算 值の差異は大きいが, それより後流ではモデル間の差異は小 さくなっていくことが確認できる。次に計測值との比較をす ると, 圧力 $0.2 \mathrm{MPa}$ の場合には, RSM での計算值は非常に よく計測值を再現していることが確認できる。しかし, 圧力 上昇とともに，RSM での計算值はすべての位置において大 きく見積もるようになっていく。それに詨して $k-\varepsilon$ モデル では，高圧下での速度場をよく再現していることが確認でき る。ただし， z/d=10より上流では計算值と計测值は大きく乘 離している。

Fig.3 に圧力 $0.2 ， 0.5,0.7,1.0 \mathrm{MPa}$ における乱流エネルギ 一の中心軸上分布を示す。本稿では計測值から算出する乱流 エネルギーを以下のように定義した。

$$
k=\frac{1}{2}\left(u^{\prime 2}+2 v^{\prime 2}\right)
$$

ここで, $u^{\prime}:$ 軸方向流速の変動 $\mathrm{rms}, v^{\prime}$ : 半径方向流速の 変動 $\mathrm{rms}$ である。

$\mathrm{RSM}$ では圧力変化に依らずピーク位置は $\mathrm{z} / \mathrm{d}=8$ 近傍, ま た乱流エネルギー強度は $k=150$ 程度で一定值を示している のに対して, $k-\varepsilon$ モデルではピーク位置はRSM よりわずか にノズル寄りの $\mathrm{z} / \mathrm{d}=7$ 近傍に現れ, 圧力上昇によらず変化 しないものの, 乱流エネルギー強度は圧力上昇にともなって 低下していく傾向が確認できる。また， $k-\varepsilon$ モデルおよび RSM の計算值は計測值と比較すると，ともに過大評価して いることがわかる。圧力上昇に伴う定性的な変化傾向はRSM の予測值が計測值と一致するが, 高圧下での乱流エネルギー の再現という観点では $k-\varepsilon$ モデルの方が計測值に一致して いる。

次に噴流の拡がり角を比較するために, 半径方向の軸方向 
高压下におけるメタン一酸素同軸乱流非予混合火炎の数值解析 (飯野・村上・吉川・赤松・香月)

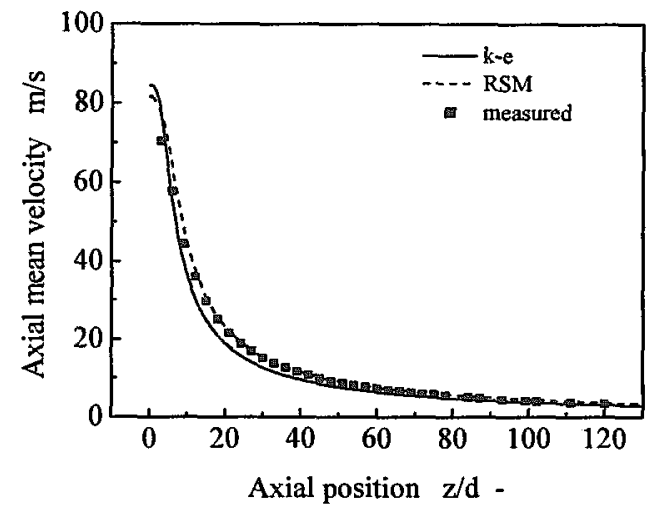

(a) $0.2 \mathrm{MPa}$

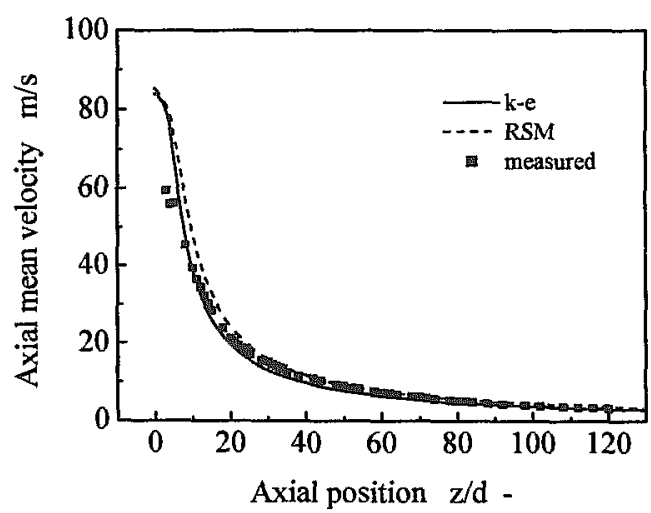

(b) $0.5 \mathrm{MPa}$

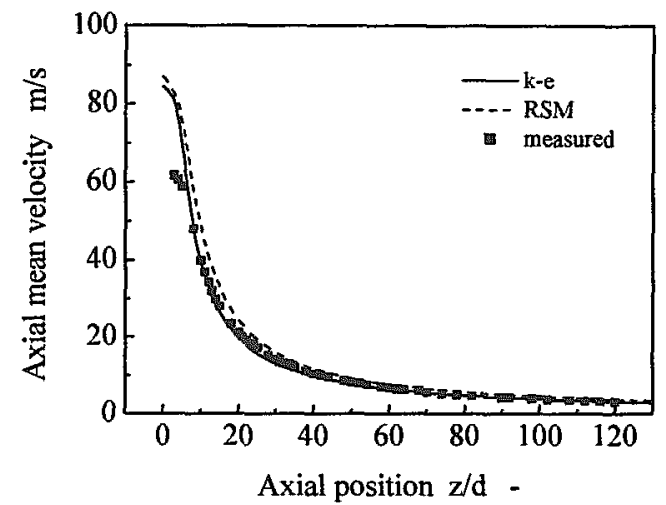

(c) $0.7 \mathrm{MPa}$

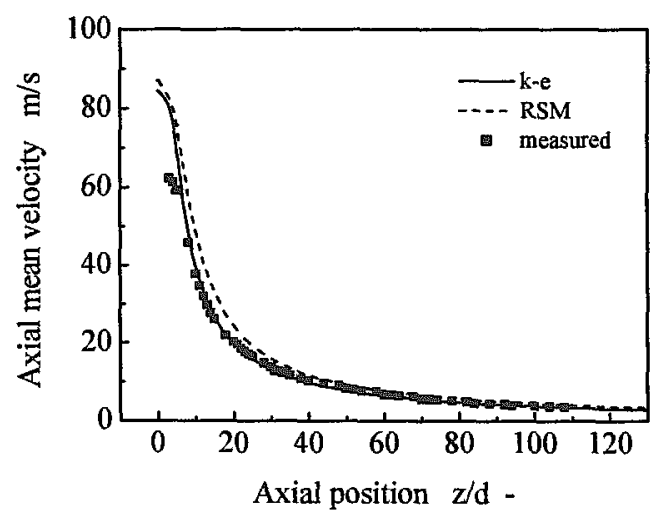

(d) $1.0 \mathrm{MPa}$

Fig. 2 Axial profiles of axial mean velocity on cold flow

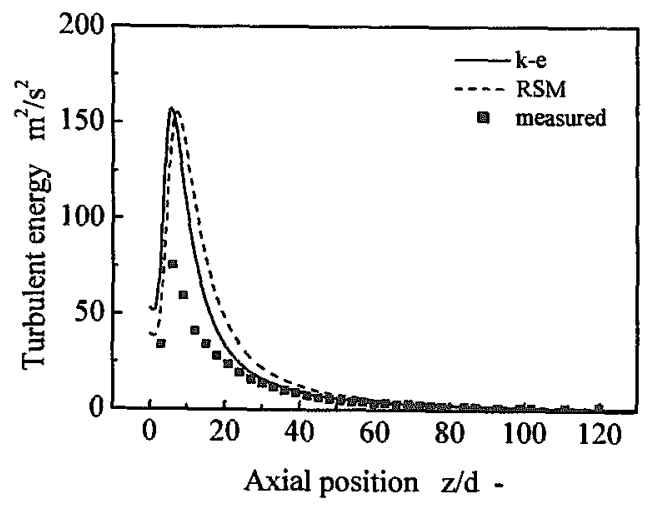

(a) $0.2 \mathrm{MPa}$

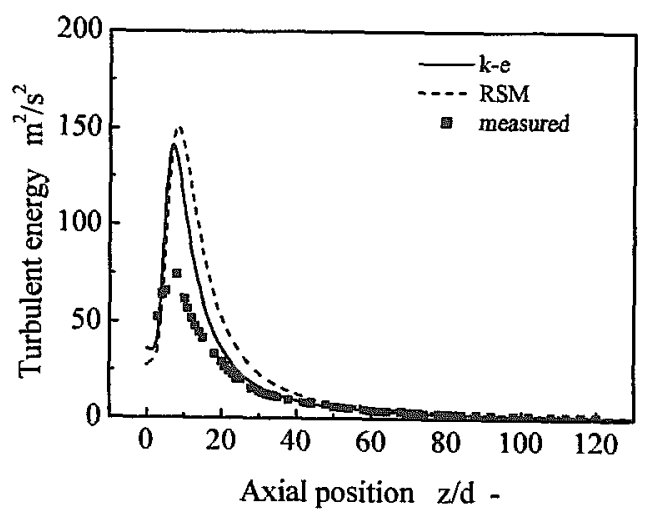

(b) $0.5 \mathrm{MPa}$

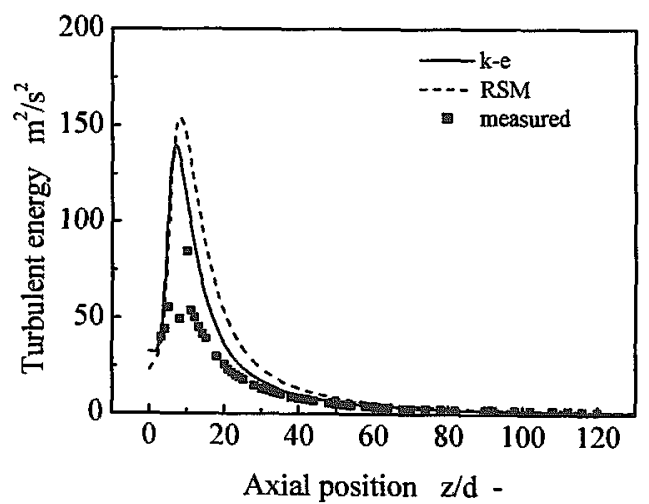

(c) $0.7 \mathrm{MPa}$

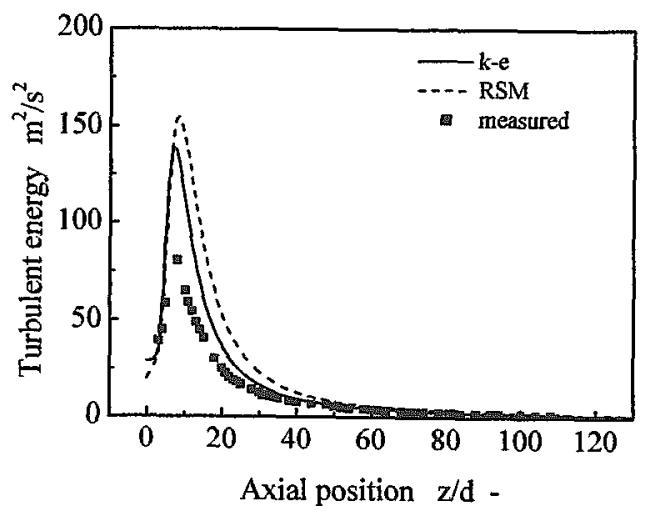

(d) $1.0 \mathrm{MPa}$

Fig. 3 Axial profiles of turbulent kinetic energy on cold flow 


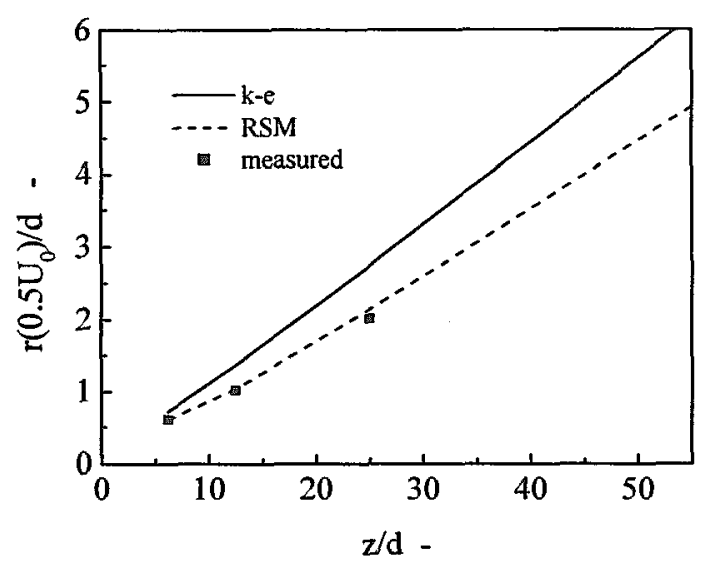

(a) $0.5 \mathrm{MPa}$

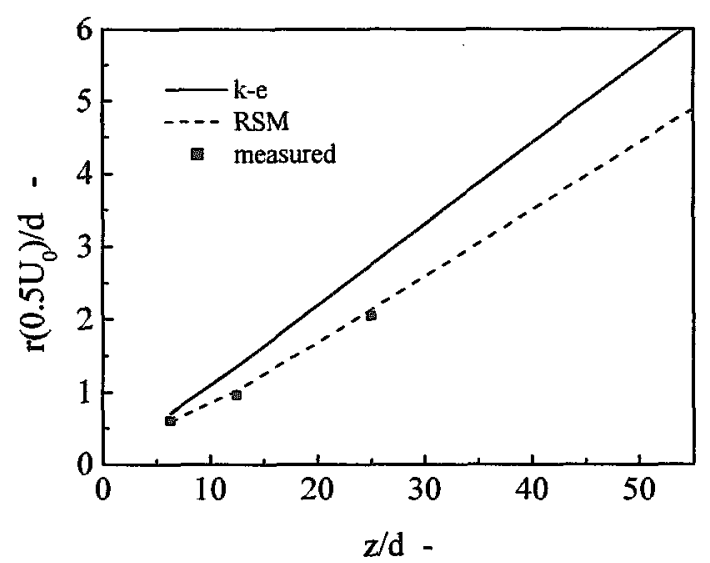

(b) $0.7 \mathrm{MPa}$

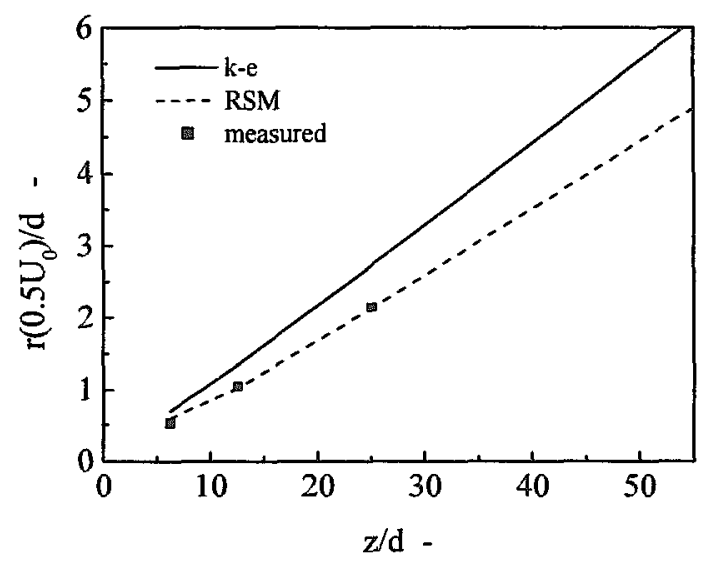

(c) $1.0 \mathrm{MPa}$

Fig. 4 Spreading angle comparison on cold flow

平均流速が中心最高流速の $50 \%$ となる噴流半径を軸上位置 との関係で表したものを，压力ごとに Fig.4に示す。2つの モデルはともに圧力上昇によらず, 拡がり角は变化しない結 果となっており，その傾向は計測值と一致している。 RSM では拡がり角が抑制されており，計測値の拡がり角をよく再 現していることが分かる。

\section{2 乱流燃焼モデルの比較}

前項の 2 つの乱流モデルと, 乱流然焼モデルとして PDF

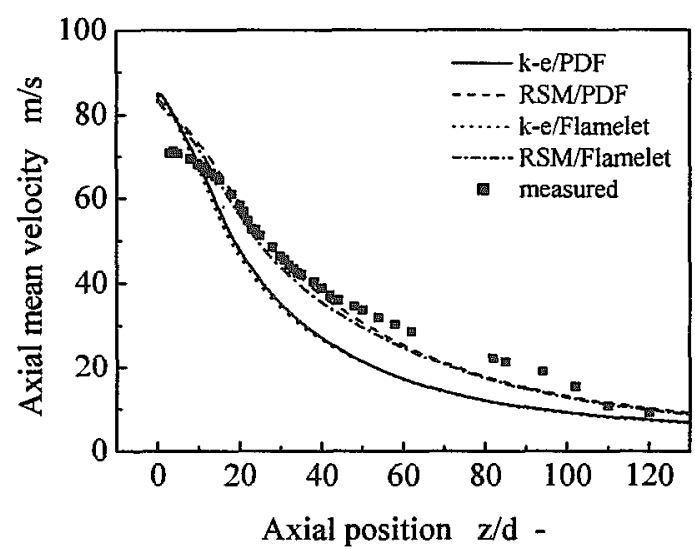

(a) $0.5 \mathrm{MPa}$

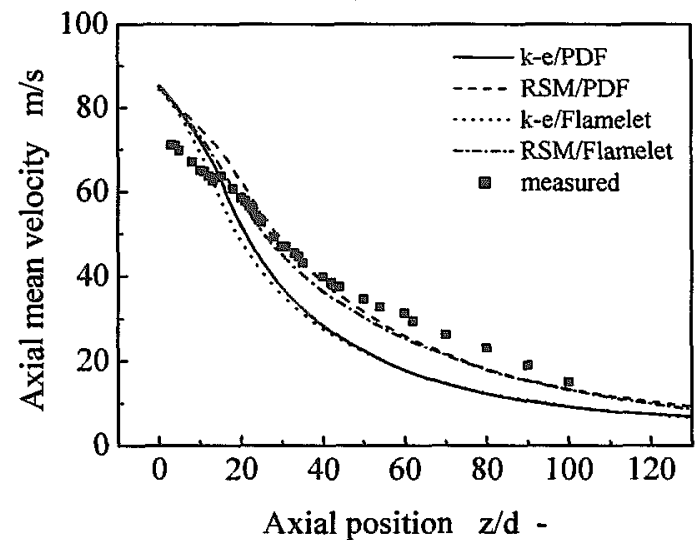

(b) $0.7 \mathrm{MPa}$

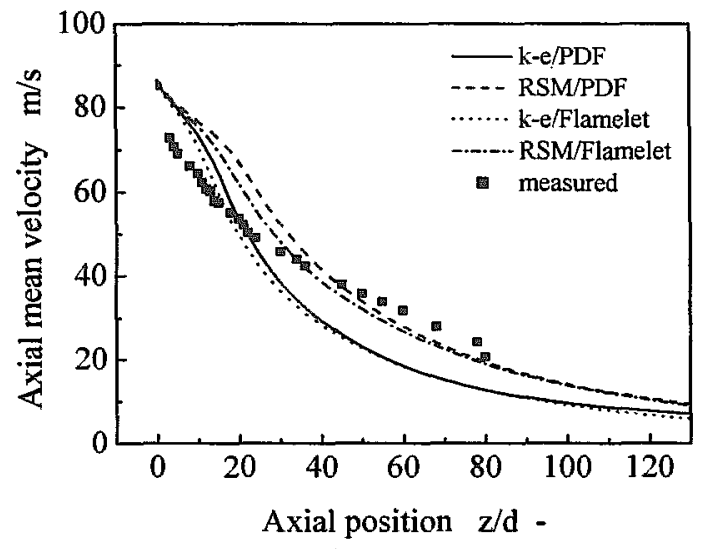

(c) $1.0 \mathrm{MPa}$

Fig. 5 Axial profiles of axial mean velocity on combusting flow

モデルおよび Flamelet モデルの 2 つを組み合わせて, 計 4 通りの計算を実施した。Fig.5 に圧力 $0.5 ， 0.7 ， 1.0 \mathrm{MPa}$ にお ける軸方向平均流速の中心軸上分布を示す。はじめに，圧力 $0.5 \mathrm{MPa}$ の場合をみると, 平衝を仮定したPDF モデルよりも， 非平衡を考慮している Flameletモデルの計算值が速度減衰を 大きく見積もっていることが確認できる。これは乱流モデル の違いによらず，同じ傾向である。しかしその差異も $\mathrm{z} / \mathrm{d}=$ 40〜60 程度でほとんどなくなり，計算值は同じ值を示すよ うになっていく。一方, 乱流モデルによる計算值の差異は, 乱流燃焼モデルによる差異よりも大きく，ノズル近傍 $\mathrm{z} / \mathrm{d}=5$ 
高压下に㧍けるメタンー酸素同軸乱流非予混合火炎の数值解析 (飯野・村上・吉川・赤松・香月)

程度までを除いて，計測領域全体にわたって一致することは なかった。 $k-\varepsilon$ モデルによる計算値よりも RSM の計算值は 速度減衰を小さく予測しており, RSM と PDF モデルの組み 合わせが計測値を最もよく再現していることが確認できる。 压力 $0.7 \mathrm{MPa}$ の場合においてむ各モデル間の変化の傾向は圧 力 $0.5 \mathrm{MPa}$ の場合と同様であるが，4通りのすべての組み合 わせにおいて，圧力上昇による速度減衰が小さくなる傾向を 示している。特に乱流モデルの違いに関わらず, PDF モデ ルの变化が大きいことが確認できる。計測值はノズル近傍 $z / d=20$ 程度までは圧力上昇によって速度減衰が大きくなる 傾向を示していることから, 計算值では逆の傾问を示す結果 となった。圧力 $1.0 \mathrm{MPa}$ では モデルを組み合わせた 2 通り の計算值は圧力上昇によってほとんど变化がないのにも関わ

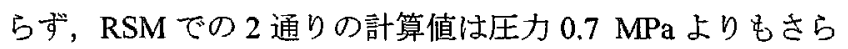
に速度減衰を小さく見積もっており，乱流モデルの差異によ る影響が大きいことが確認できる。RSMの場合にはPDF モ デル, Flamelet モデルともに $/ \mathrm{d}=10 \sim 30$ 程度の範囲で圧力 上昇による速度減衰が小さくなっており，この範囲での計測 值との乘離注圧力 $0.7 \mathrm{MPa}$ の場合よりさらに大きくなる結果 となった。筆者らは既報”において，圧力上昇に伴う乱流場 の非等方性の増大を確認しており,これら乱流モデルの予測 傾向の差異はモデル化の過程における等方性理論の採用に限 界があることを示しているものと推測される。また，さらに 火炎長が圧力変化によらず一定値を示す結果より, 単位体積 当たりの熱発生量の増加による温度变動ならびに密度变動の 増大が引き起こされ，モデル化の過程において省略される高 次相関項や密度変動に関係する項の影響が大きくなる可能性 を示唆しているものと推測される。

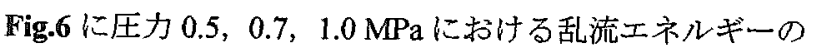
中心軸上分布を示す。压力 $0.5 \mathrm{MPa}$ の場合では， $k-\varepsilon$ モデ ルとの 2 通りの組み合わせでは, 乱流エネルギーのピーク位 置はほとんど差異はなく, PDF モデルの計算值が乱流エネ ルギー強度を若干大きく見積もっている。一方, RSM との 2 通りの組み合わせでは，乱流エネルギー強度はほとんど差 異がなく，Flamelet モデルの方がピーク位置が若干ノズルに 近いところに現れている。RSM の乱流エネルギー強度はピ 一ク以降の減衰が $k-\varepsilon$ モデルに比較して緩やかであり，z/d $=30 〜 40$ 程度の位置において乱流エネルギー強度の値は $k-\varepsilon$ モデルの計算值と逆転し，その後は RSMの方が大きく なる。ピーク位置については， $k-\varepsilon$ モデルの計算值が RSM の場合に比較してノズル側に現れている。計測值との比較を 行うと, 全ての組み合わせにおいて $\mathrm{z} / \mathrm{d}=50$ 程度までは過大 予測をしており，特に $k-\varepsilon$ モデルでの計算值とのピーク值 の挒離は 2 倍程度と大きくなっている。圧力 $0.7 \mathrm{MPa}$ では， ピーク位置, 乱流エネルギー強度ともに各モデル閒の差異が 大きくなっていることがわかる。 $k-\varepsilon$ モデルとの組み合わ せでは圧力上昇によって，ノズル近傍では乱流エネルギー强 度の減少が大きくなっている。また，圧力上昇によってピー ク位置は若干ノズルから離れる傾向を示し, 乱流エネルギー

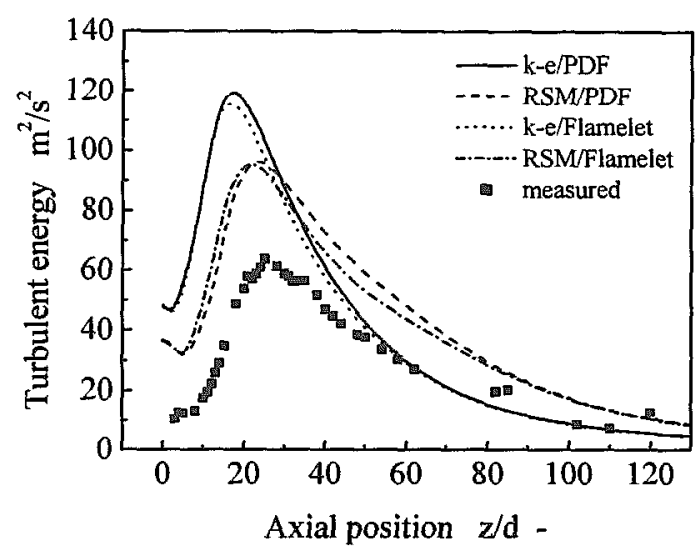

(a) $0.5 \mathrm{MPa}$

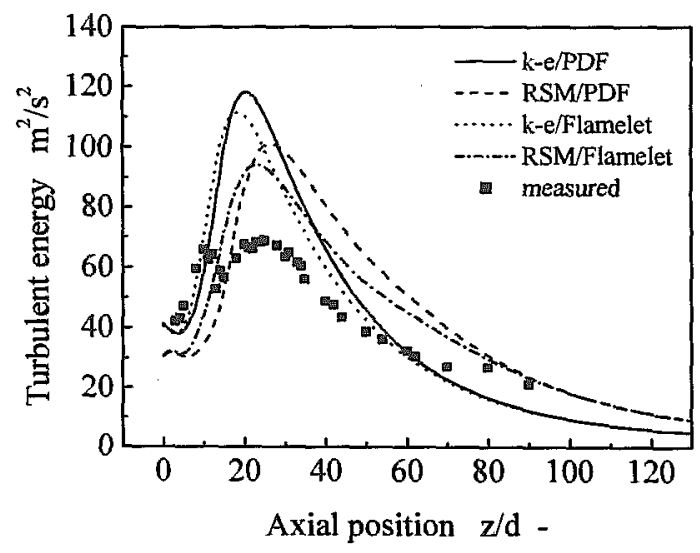

(b) $0.7 \mathrm{MPa}$

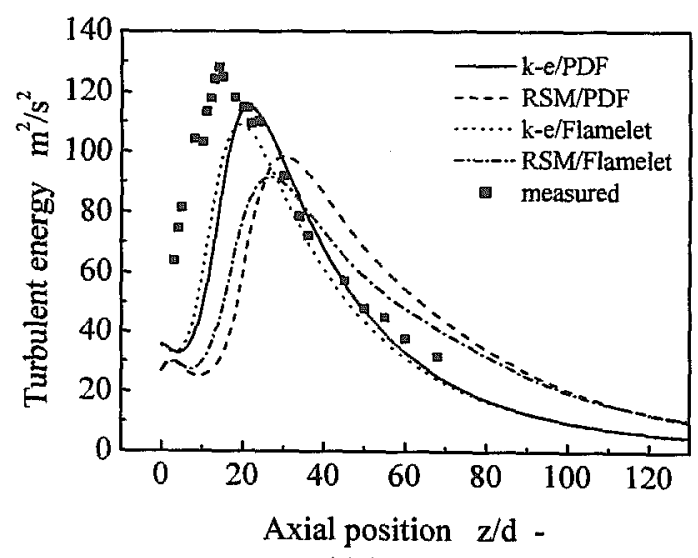

(c) $1.0 \mathrm{MPa}$

Fig. 6 Axial profiles of turbulent kinetic energy on combusting flow

强度は減少する傾向を示している。特に，Flamelet モデルで の減少の幅が大きくなっている。それに対して，RSM では ピーク位置については モデルの場合と同様に圧力上昇に伴 いノズルから離れる傾向を示すが，乱流エネルギー強度は PDF モデルと Flamelet モデル間で異なり，PDF モデルの場 合に増大寸る傾向を示している。これは計測值の圧力上昇に よる変化と同様な傾向を示吉結果となっている。圧力 $1.0 \mathrm{MPa}$ においては,圧力上舁によるピーク位置の変化は圧力 $0.7 \mathrm{MPa}$ の場合と同様にノズルから離れていく結果を示している。そ して圧力 $0.7 \mathrm{MPa}$ で確認された RSM/PDF モデルでの乱流エ 


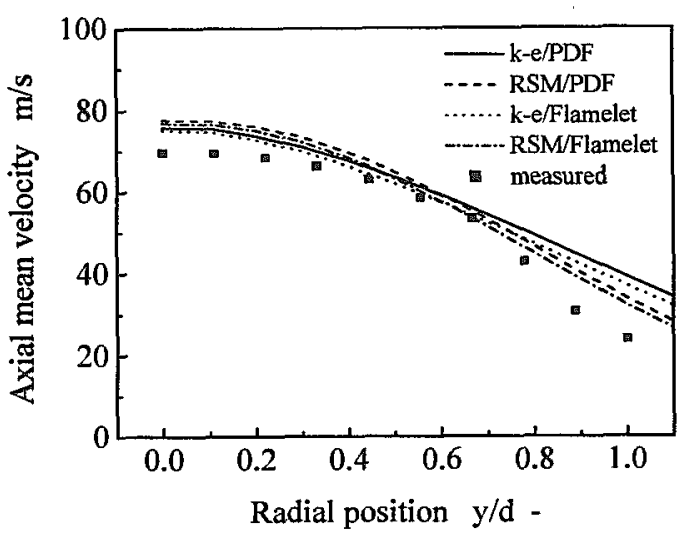

(a) $0.5 \mathrm{MPa}$

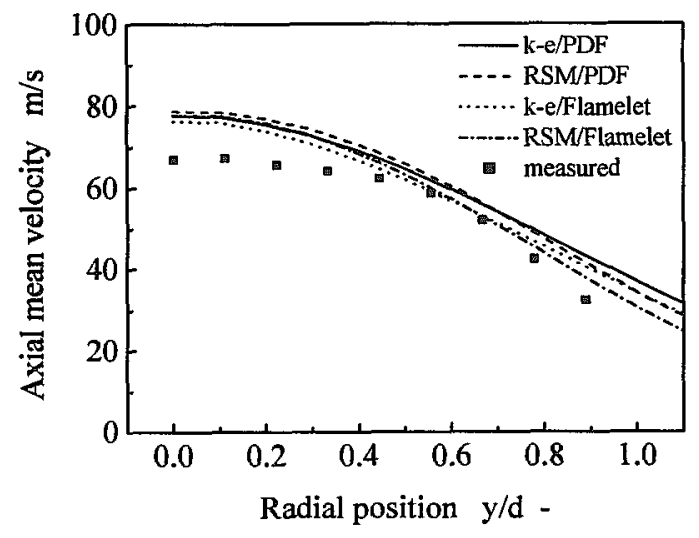

(b) $0.7 \mathrm{MPa}$

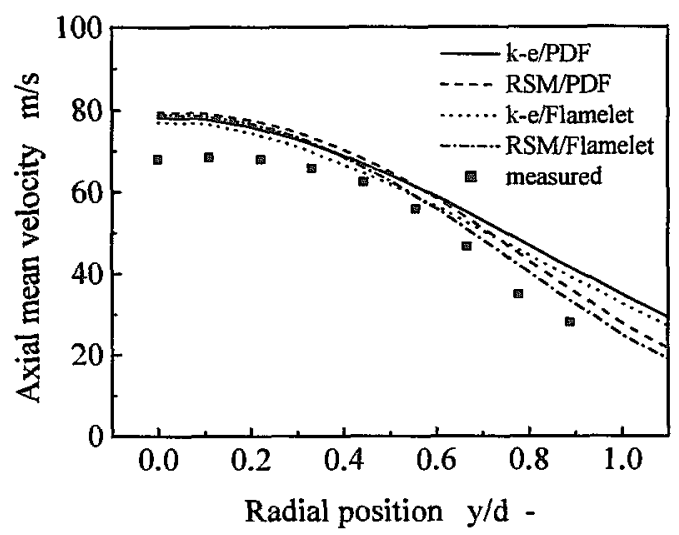

(c) $1.0 \mathrm{MPa}$

Fig. 7 Radial profiles of axial mean velocity on combusting flow at $\mathrm{z} / \mathrm{d}=6.25$

ネルギー強度の圧力上昇に伴う増大は確認されず, 圧力 0.7 $\mathrm{MPa}$ の場合と同程度となる計算結果を得た。また, $k-\varepsilon$ モ デルでは圧力上昇によって，さらにノズル近傍での乱流エネ ルギー強度の減少が大きくなっていることが確認できる。

Fig.7, 8 に圧力 $0.5,0.7,1.0 \mathrm{MPa}$ における $\mathrm{z} / \mathrm{d}=6.25,50$ での軸方向平均流速の半径方向分布を示す。また計測值の軸 対称性を確認するためにFig.9に圧力 $0.5 ， 0.7 ， 1.0 \mathrm{MPa}$ にお ける $\mathrm{z} / \mathrm{d}=6.25$ での軸方向平均流速の半径方向分布を示す。こ れよりすべての条件において対称性が維持されていることが 確認できるため, 以降では一方の半径方向分布に関してのみ

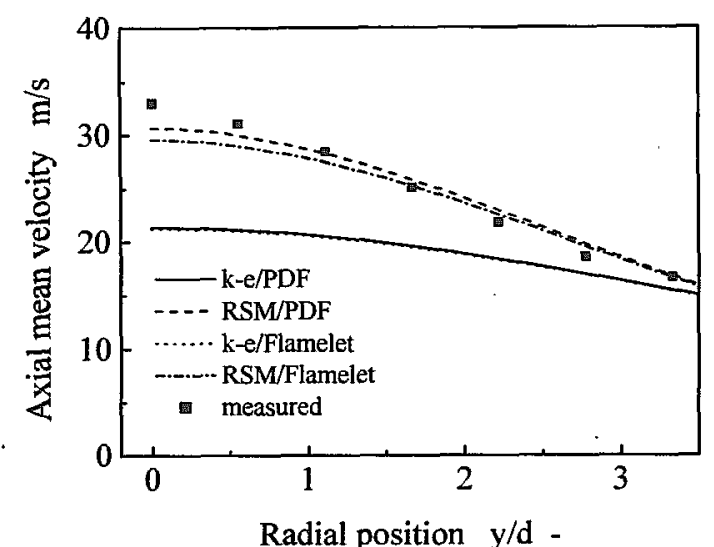

(a) $0.5 \mathrm{MPa}$

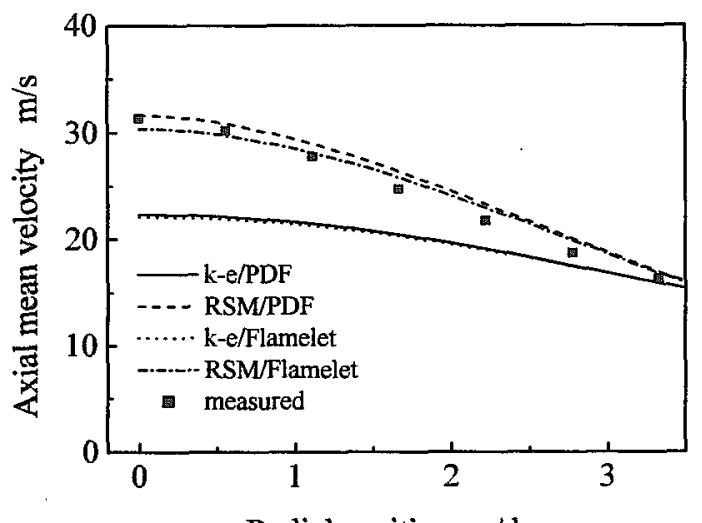

Radial position $\mathrm{y} / \mathrm{d}$ -

(b) $0.7 \mathrm{MPa}$

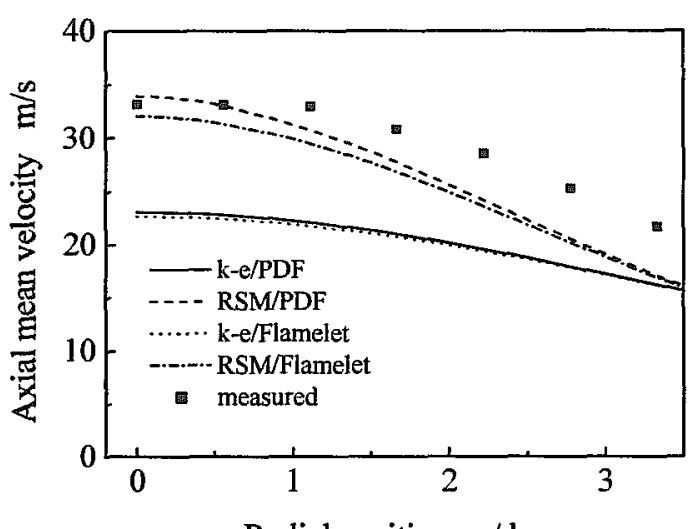

Radial position $\mathrm{y} / \mathrm{d}$ -

(c) $1.0 \mathrm{MPa}$

Fig. 8 Radial profiles of axial mean velocity on combusting flow at $\mathrm{z} / \mathrm{d}=\mathbf{5 0}$

議論を倠めることとした。はじめにz/d=6.25について見ると， すべての圧力において乱流モデル間の差異が特徵的に現れて いることがわかる。 $k-\varepsilon$ モデルとの 2 通りの組み合わせで は，分布形状が RSMに比較して緩やかになっており，速度 减衰が小さいことが確認できる。また，全てのモデルにおい て圧力上昇によって，中心部では速度が若干増加し，外端部 では速度減衰が大きくなり，速度は減少する結果となってい る。計測值との比較においては，圧力に依らず中心部，外端 
高圧下におけるメタンー酸素同軸乱流非予混合火资の数值解析 (飯野・村上・吉川・赤松・香月)

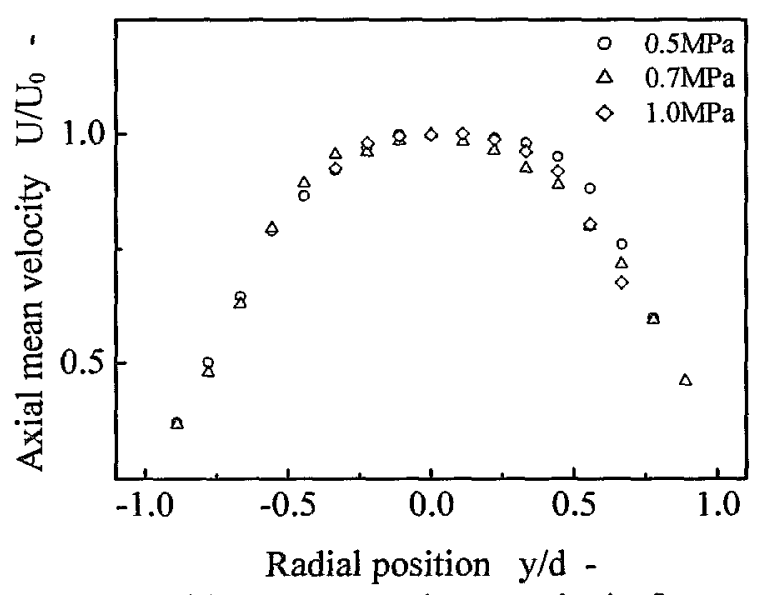

Fig.9 Axial symmetry comparison on combusting flow

部で計算值は過大予測をしているが，外端部での圧力上昇に よる速度減衰傾向はすべての計算で再現できている。 z/d= 50 においては，さらに乱流モデル間の差異は大きくなって おり，特に中心部では $k-\varepsilon$ モデルの計算值が RSMに比較し て 75\%程度の值となっている。さらに, $\mathrm{z} / \mathrm{d}=6.25$ で確認され た分布形状の差異は，この位置においても確認でき， $k-\varepsilon モ$ デルの速度減衰は緩やかになっている。圧力 $0.5 \mathrm{MPa}, 0.7 \mathrm{MPa}$ では RSM での 2 つの組み合わせはともに計測値をよく再現 しているが，压力 $1.0 \mathrm{MPa}$ では外端部での速度隇衰を大きく 予測しており，計測值と最大で $25 \%$ 程度の乘離があること が確認できる。

次に, 非燃焼時上同様に噴流の拡がり角を比較するために 噴流半径と軸上位置との関係を Fig.10 に示す。ここでも乱 流モデルによる差異が乱流然焼モデルによる影響より大きく なっている。また, 非燃焼時と同様に $k-\varepsilon$ モデルよりも RSM で濆流の拉がりが抑制され，搪がり角が小さくなっている ことが確認できる。さらに，乱流モデルの中でも PDF モデ ルの計算值の方がノズルから離れた位置では搪がりが抑制さ れる結果となっている。圧力による変化を見ると，計算値で はすべての場合におかい，圧力上昇に伴い拡がりが抑制され， 拡がり角が小さくなる傾向を示しており，計測值とは反対の 傾向を示す結果となった。計測值との比較においては，圧力 $0.5 \mathrm{MPa}, 0.7 \mathrm{MPa}$ の場合にはすべての組み合わせにおいて拡 がりを大きく予測しているが, 压力 $1.0 \mathrm{MPa}$ の場合には RSM での2つの計算値は計測值の傾向をよく再現していることが 確認できる。

\section{4. 結 言}

従来, 高圧燃焼場における各種乱流モデルおよび乱流然焼 モデルの適用性を高压下での詳細な計测データとの比較・検 討を行うことにより評伍した研究例は存在しない。今回，高 圧燃焼場に関してはじめてそれを行い，各モデルの予測傾向 に関して検証を行った。以下は得られた結論である。

(1) 非燃焼時においては $k-\varepsilon$ モデルが高圧下での速度場を よく再現していることが確認できた。ただし，z/d=10より上

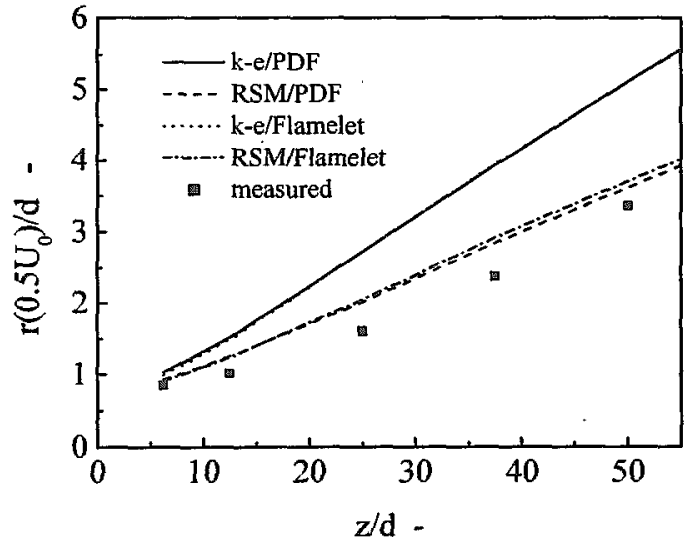

(a) $0.5 \mathrm{MPa}$

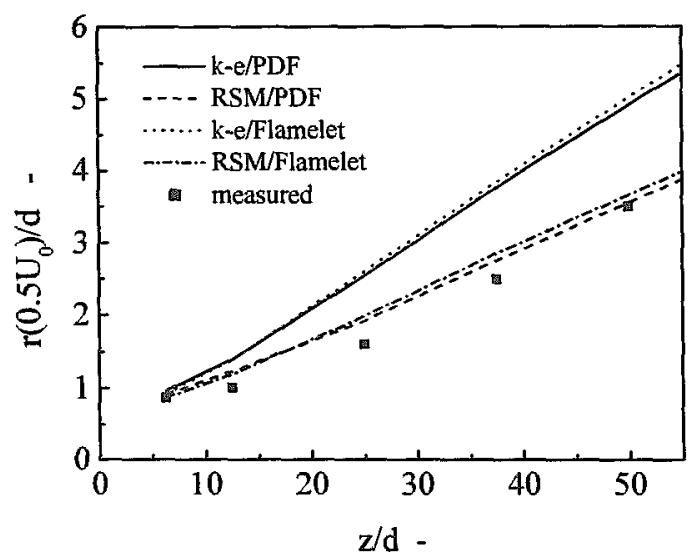

(b) $0.7 \mathrm{MPa}$

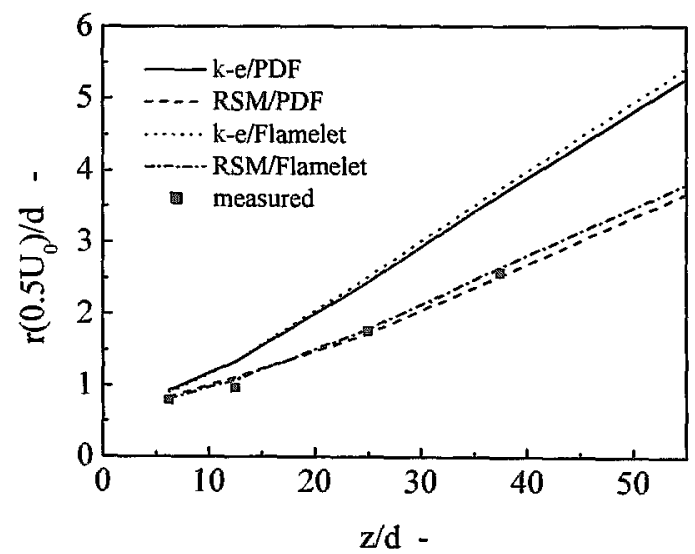

(c) $1.0 \mathrm{MPa}$

Fig. 10 Spreading angle comparison on combusting flow

流では計算值と計測值は大きく乘離している。

(2) 高压下に㧍ける乱流エネルギーの予測に関して，圧力 上昇に伴う定性的な変化傾向はRSM の予測值が計測值と一 致するが, 高圧下での乱流エネルギーの再現という観点では $k-\varepsilon$ モデルの方が計測値に一致する。

(3) $k-\varepsilon$ モデルおよびRSM は，ともに压力上舁によらず拡 がり角は変化しない結果となっており，その傾问は計測值と 一致した。特に，RSM では搪がり角が抑制されていること が確認でき，計測值の拡がり角をよく再現している。 
(4) 高圧然焼場における中心軸上の軸方向平均流速予測に 関して,乱流モデルによる計算值の差異は乱流燃燒モデルに よる差異よりも大きく，ノズル近傍 $\mathrm{z} / \mathrm{d}=5$ 程度までを除い て, 計測領域全体にわたって一致することはなかった。 $k-\varepsilon$ モデルによる計算值よりも RSM の計算值は速度減衰を小さ く予測しており，圧力 $0.5 \mathrm{MPa}$ においては RSM と PDF モデ ルの組み合わせが計測值を最もよく再現している。しかし， 圧力上昇に伴ら速度減衰傾向は再現されて抢らず，特に z/d $=30$ 程度までの位置での計測值と計算值の乘離が大きくな る。

（5）高圧燃焼場における軸方向平均流速の半径方向予測に

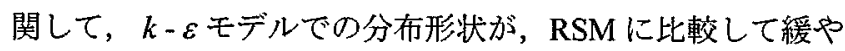
かになっており，速度隇衰が小さいという傾向がすべての圧 力において特徽的に現れることを確認した。z/d=6.25 では 圧力に依らず中心部，外端部で計算值は過大予測をしている が，外端部での圧力上昇による速度減衰傾向はすべての組み 合わせの計算で再現できている。z/d=50kおいては，乱流 モデル間の差異はさらに大きくなっており，特に中心部では $k-\varepsilon$ モデルの計算值が RSMに比較して75\%程度の値となっ ている。圧力 $0.5 \mathrm{MPa}, 0.7 \mathrm{MPa}$ では RSM との 2 つの組み合 わせはともに計測値をよく再現しているが, 圧力 $1.0 \mathrm{MPa}$ で は外端部での速度減衰を大きく予測しており, 計測值と最大 で 25\%程度の乘離がある。

（6）高圧燃焼場における中心軸上の乱流エネルギー予測に 関して, 計算值では圧力上昇に伴ってピーク位置がノズルか ら離れていくという結果を示し, 計測值の傾向を再現する結 果は得られなかった。また RSM/PDF モデルの組み合わせ以 外では, 乱流エネルギーが圧力上昇によって減少傾向を予測 する結果となり，計測值とは反対の傾向を示す。
（7）高圧燃焼場での拡がり角予測に関して，計算值ではす べての組み合わせにおいて，圧力上昇に伴い搪がりが抑制さ れ，拡がり角が小さくなる傾向を示しており，計測值とは反 対の傾向を示す結果となった。圧力 $0.5 \mathrm{MPa}, 0.7 \mathrm{MPa}$ の場 合にはすべての組み合わせにおいて拡がり角を大きく予測し ているが，圧力 $1.0 \mathrm{MPa}$ の場合には RSM モデルを採用した 計算値は計測值の傾向をよく再現している。

\section{引用文 献}

1) 飯野公夫, 赤松史光, 香月正司: 高温学会誌, 投稿中

2) 飯野公夫, 吉川星高, 赤松史光, 香月正司 : 高温学会誌, 投稿 中

3）飯野公夫，近野直治，讃井宏：日本酸素技報，（1994）17-21.

4）五十風弘，阿部智信，三宅新一，鹫見郁宏，菞池良輝：日本酸 素技報，（2003） 7-12.

5) Prince B. Eleazer and Aleksandar G. Slavejkov : Ceram. Eng. Sci. Proc. 15-2 (1994) 159-174.

6) JC. Sautet, L. Salentey and M. DiTaranto : Int. Comm. Heat Mass Transfer, 28-2 (2001) 277-287.

7) Charles E. Baukal, Jr : Oxygen-enhanced combustion, (1998), CRC Press.

8) G.D. Raithby and E.H. Chui : J. Heat Transfer, 112 (1990) 415-423.

9) E.H. Chui and G.D. Raithby : Numerical Heat Transfer, Part B, 23 (1993) 269-288.

10) B.E. Launder : Int. J. Heat Mass Transfer, 15-1 (1972) 301-306.

11) M.M. Gibson and B.E. Launder : J. Fluid. Mech., 86 (1978) $491-511$.

12) Y.R. Sivathanu and G.M. Faeth : Combust. Flame, 82 (1990).211-230.

13) N Peters : Prog. Energy Combust. Sci, 10 (1984) 319-339.

14) P.A. Libby and F.A. Williams : Turbulent Reacting Flows Academic Press (1994) 63-114 